\title{
Silage Crops for Dairy and Beef Cattle I: Corn ${ }^{1}$
}

\section{Marcelo Wallau, Joao Vendramini, Adegbola Adesogan, Diwakar Vyas, and Kevin Korus ${ }^{2}$}

Silage is a method of preserving forage through fermentation in an anaerobic environment. Bacteria present on the crop and those that are introduced later (inoculated) use soluble sugars to produce acids that prevent growth of other detrimental, spoilage-causing microorganisms. Silage production is a preferred method of feed storage for energy-dense crops, such as corn and sorghum, and in areas where haymaking is challenging given the environmental conditions (e.g., excessive rain). Corn silage is an important feed source for dairy cattle in Florida, and sorghum silage is becoming more common in the beef cattle industry. Corn silage is preferred for dairies because it generally can produce the most energy per acre with less labor required. Meanwhile, sorghum requires less fertilization and maintenance, and is generally the choice for low-input systems. The level of ensiling success, product quality, and length of storage all depend on the initial characteristics of the material, such as soluble carbohydrates, moisture at harvest, length of chopping, and compaction (i.e., excluding oxygen).

Silage production and feeding, however, entails large investments in machinery and labor, and requires technical expertise. Good fermentation during the ensiling process preserves quality of the forage. However, inadequate fermentation can lead to great losses in dry matter (DM), quality, and acceptability. Spoiled silage can have high levels of mycotoxins which are detrimental to animal production and can be lethal. Furthermore, large amounts of inputs are required to grow a decent crop for ensiling. This Ask IFAS series covers crop choices and agronomic aspects of silage production in Florida, from planting until preparing to harvest, and is divided into two publications: corn (Ask IFAS publication SS-AGR-69), and sorghum and other forage crops (Ask IFAS publication SS-AGR-461). More information on corn production can be found in Ask IFAS publication SS-AGR-85, Field Corn Production Guide (https://edis.ifas.ufl.edu/ag202). Information on harvesting, storage, and utilization can be found in Ask IFAS publication SS-AGR-177, Silage Harvesting, Storing, and Feeding (https://edis.ifas.ufl.edu/publication/AG180). Information on haylage can be found in Ask IFAS publication AN145, Harvesting, Storing, and Feeding Forages as Round Bale Silage (https://edis.ifas.ufl.edu/publication/AN145).

\section{Crop Options}

Many commonly grown forage crops can be harvested and stored as silage. Some of those that are grown or have been grown in Florida are listed below as either high-energy or low-energy silage crops. High-energy crops have a greater concentration of non-structural carbohydrates (e.g., simple sugars and starch) which enhance fermentation. Low-energy crops ferment more slowly and require lower

1. This document is SS-AGR-69, one of a series of the Agronomy Department, UF/IFAS Extension. Original publication date April 2003. Revised August 2012 and February 2022. Visit the EDIS website at https://edis.ifas.ufl.edu for the currently supported version of this publication.

2. Marcelo Wallau, assistant professor and forage Extension specialist, Agronomy Department; Joao Vendramini, associate professor and forage specialist, UF/IFAS Range Cattle Research and Education Center; Adegbola Adesogan, professor, Department of Animal Sciences; Diwakar Vyas, assistant professor, Department of Animal Sciences; and Kevin Korus, agricultural Extension agent II, UF/IFAS Extension Alachua County; UF/IFAS Extension, Gainesville, FL 32611.

The use of trade names in this publication is solely for the purpose of providing specific information. UF/IFAS does not guarantee or warranty the products named, and references to them in this publication do not signify our approval to the exclusion of other products of suitable composition.

The Institute of Food and Agricultural Sciences (IFAS) is an Equal Opportunity Institution authorized to provide research, educational information and other services

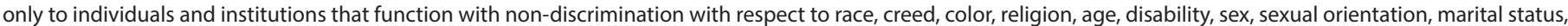

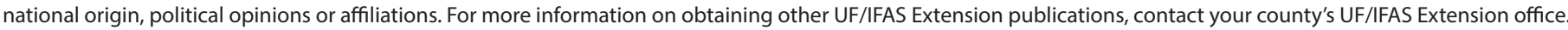
U.S. Department of Agriculture, UF/IFAS Extension Service, University of Florida, IFAS, Florida A \& M University Cooperative Extension Program, and Boards of County Commissioners Cooperating. Andra Johnson, dean for UF/IFAS Extension. 
moisture levels to avoid spoilage. High-energy crops are generally used in dairy systems and yield the greatest amount of energy per acre. The dry matter yield of forage sorghum can be similar to that of corn, although nutritive value is typically lower, resulting in fewer nutrients harvested per area (and equivalent estimated milk production per area). Nutritive value of grain sorghum silage is usually similar to that of corn silage, but biomass yield is typically lower compared to forage sorghum ( 14\%) (Bean et al. 2013) and is seldom used in Florida. As a general rule, the lower the grain content, the lower the silage's energy content. Sorghum x sudan hybrids (Sorghum $\times$ drummondii), sudangrass, and pearl millet have greater potential for grazing or green chop (i.e., multiple cuts) but can also be ensiled. Sorghums and millets can produce one or more ratoon crops that can be grazed. Ratoon crops are normally not utilized on dairy systems, because production tends to be much lower compared to the first crop and is best when cut earlier (i.e., not at full maturity). Those are more suited for green chop or grazing. In northern climates or the western United States, alfalfa silage is very common, but in Florida, most legumes are not productive enough to justify ensiling. Perennial peanut and alfalfa-bermudagrass mix baleage are seen more frequently, especially in wet years when baling hay is problematic. Cool-season forages, including small grains and annual ryegrass, are a good option for planting in sequence with corn and can produce great silage as well. Silage of perennial forage crops (e.g., bermudagrass, limpograss) are popular in south Florida and frequently found on beef cattle operations to be used as a complementary source of forage for the off-season. The low level of soluble carbohydrates $(<6 \%)$ in low-energy crops can pose challenges for ensiling, and a lower moisture level (50\%) is required to prevent spoilage.

\section{High-Energy Silage Crops}

\section{- Corn}

- Sorghum (Milo)

- Grain

- Forage

\section{Low-Energy Silage Crops}

- Perennial grasses

- Bermudagrass and stargrass

- Limpograss (Hemarthria)

- Other improved perennial grasses

- Other annual grasses

- Sudangrass and sorghum x sudangrass hybrids
- Pearl millet

- Small grains and ryegrass

- Legumes

- Alfalfa

- Red clover and other cool-season legumes

- Sunn hemp

- Other summer legumes (hairy indigo, alyceclover, Aeschynomene, and rhizoma perennial peanut)

Other crops can be ensiled, such as sugarcane and certain crop combinations (i.e., grain sorghum and soybeans, or ryegrass and red or white clover). The following sections present some general agronomic characteristics and management requirements for commonly ensiled crops in Florida. The information is divided by crop species, although some share multiple resources, and information can be cross-referenced.

\section{Corn Silage}

Most production practices for growing corn (Zea mays L.) silage are the same as for grain production. In north central and northwest Florida, corn can be grown without irrigation, but yields are usually relatively low $(<20-25 \%)$ compared to irrigated corn. Irrigation and adequate drainage are necessary when growing corn on the mineral and organic soils in south Florida. In dairy systems, irrigation is frequently done through effluent application and is an efficient way to recycle nutrients and lower fertilizer input costs. In most parts of Florida, corn can be planted and harvested twice in the same cropping season, although crop rotation is essential for disease and pest management, especially of soilborne nematodes. Other summer annual crops can be planted after corn and used for silage, grazing, or for cover and nutrient management. Here, we present general aspects of corn production for silage. See Ask IFAS publication SS AGR 85, Field Corn Production Guide, for a more complete guide on field corn production (https://edis. ifas.ufl.edu/ag202).

\section{Hybrid Selection}

Selection of genetic materials is extremely important for the success of silage production and the first line of defense against pests and diseases in corn. Pest resistance is essential in Florida, given the favorable environmental conditions for insects and fungal disease (see Pests and Diseases). There are various corn hybrids available in the market. Those are developed for different purposes (i.e., silage, grain, or dual-purpose) and adapted to different environments. The various "trait packages" of differing hybrids 
offer resistance to multiple pests, tolerance to herbicides, and "stay-green" characteristics that can enhance silage quality and production. The UF Forage Team conducts annual hybrid trials in partnership with seed industries to evaluate corn and sorghum hybrids best adapted to north central Florida. Corn and sorghum are planted in the spring and summer, and the trials are open for any seed company to enter. Although the list is not a comprehensive evaluation of all hybrids in the market, it showcases the most popular and promising materials adapted to Florida's environmental conditions. See https://animal.ifas.ufl.edu/extension/ courses/csfd/ for historical data and extra information on nutritive value and agronomic characteristics of corn and sorghum hybrids.

Productivity and disease resistance are the primary factors affecting hybrid selection. Beyond dry matter production (or equivalent silage, corrected to $35 \%$ dry matter), nutritive value is important for achieving desirable animal productivity. To account for both quantity and quality parameters, our results also present the estimated milk production per ton of silage and per acre (Milk 2006; Shaver et al. 2006). Estimates of disease severity are also given and are based on visual assessment of leaf lesions. The ideal silage types have high forage yields (more than 9 dry tons per acre), are low in neutral detergent fiber (NDF), and have high NDF digestibility (more than 50\% NDF digestibility after 30 hours of digestion-NDFD30). High NDF digestibility reduces rumen fill and increases passage rate. Each percentage point higher in NDF digestibly represents an extra $0.37 \mathrm{lb}$ of dry matter intake and $0.5 \mathrm{lb}$ of milk yield per day (Oba and Allen 1999). Corn hybrids can be divided into three relative maturity groups-full-season (>120 days), mid-season (115 days), and early-season (110 days). The full-season hybrids silk five to ten days later than the early-season hybrids and require more time to fill the ear before reaching maturity. Choosing hybrids of different maturity and stacking planting dates are strategies to scale planting and harvesting. This is important because a few days' delay in harvesting can significantly reduce the nutritive value and moisture as plants mature. The harvest period can be lengthened by planting an early-season hybrid first and a full-season hybrid last. The full-season hybrids generally produce larger plants and a higher tonnage of silage. Early-season hybrids may produce as much grain, but on smaller plants. As a result, total silage yield is usually lower, but percentage grain in the silage is higher in early-season hybrids. Stay-green traits can give more flexibility on harvest as leaf senescence is delayed.

\section{Planting Dates}

Planting should occur when soil temperature and moisture conditions are favorable for germination and growth. The minimum threshold temperature for corn seed germination is $50^{\circ} \mathrm{F}$. To reduce the chance of stand loss due to a late freeze, producers in north Florida utilizing no-till practices should wait until after March 1 to plant. Those planting on dryland acres often delay planting so that tasseling and pollination occur after the May drought. In south Florida, because of the very low risk of frost, most producers start planting corn in early February. Corn planted after the recommended dates is more likely to suffer from attacks by foliage-feeding worms and diseases. Furthermore, challenging weather conditions in early summer can hinder harvesting and result in reduction of silage quality or even loss of crop. Growers should switch to sorghum (tropical corn hybrids are generally not available in the market) if additional silage acreage is needed after the recommended planting dates for corn have passed.

A second, summer corn crop is possible. Planting generally occurs right after harvesting the spring corn, in May (south Florida) or late June to early July (north central Florida). However, double-cropping with the same species within a year is not a recommended practice. Crop rotation is essential to break the cycle of pests and diseases. While tillage can eliminate some issues related to inoculum on crop residue, soilborne pests such as nematodes and some fungal diseases can be a major problem, and alternative management practices can be very expensive (see Pests and Diseases).

\section{Planting}

With irrigation, ideal density is $26,000-36,000$ corn plants per acre. Without irrigation, plant population should be based on the ability of the soil to supply and retain moisture during the growing season. As the holding capacity for soil moisture decreases, so should the plant population. Additionally, check the plant population recommended by the seed corn company for the specific hybrid being planted. Always check germination of your seed lot so you can adjust planting rates to ensure adequate plant populations. See your planter operator's manual for instructions on planter calibration. After calibration, always double-check the seeding rate and planting depth on the seed row. The target planting depth should be between 1.5 and 2 inches. Row width can vary from 15 - to 40 -inch centers, but most corn growers use rows 30-36 inches wide. This row width facilitates cultural practices such as side dressing nutrients and herbicide applications. Narrow rows complicate spraying and fertilization applications, while wide rows 
reduce resource use efficiency and create space for weeds to emerge.

Corn can be planted on a prepared seedbed (Figure 1A), no-till (Figure 1B), or strip-tilled (Figure 1C) after harvesting cool-season forages/cover crops (see Small Grain section). No-till requires a seeder equipped with knife or disk coulters, or row cleaners, and eliminates the need for multiple passes for cultivation. It does require a burndown herbicide, generally glyphosate or paraquat, to eliminate competition from the previous crop. Crop residue, however, offers ground cover, reduces dry out, reduces variation in soil temperature, and suppresses weed emergence. A systemic herbicide (glyphosate) is recommended when planting corn after ryegrass (Figure 1B) because ryegrass can still grow after cutting and can increase competition for corn. Strip tillage is an option where just the row is cultivated and still offers decent ground cover (Figure 1C).

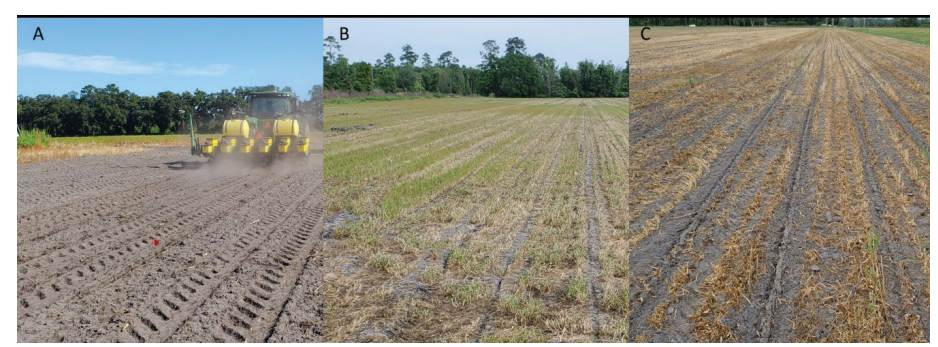

Figure 1. (A) Corn on prepared seedbed; (B) no-till after ryegrass; and (C) strip-tilled after oat.

Credits: Marcelo Wallau, UF/IFAS

\section{Liming and Fertilization}

Any fertilization program should be based on a soil test to avoid under- or overfertilization. Soil grid sampling and yield maps are great tools that can be used to fine-tune fertility needs and frequently result in savings on fertilizer and lime cost. Manure and effluent spray should be tested for their plant nutritive value before being applied. UF/IFAS has a livestock waste testing lab (https://edis.ifas.ufl.edu/ ss599) that can analyze manure and similar amendments. Adequate fertilization, especially early in the season, can determine crop productivity. A fertilization guide can be found in Ask IFAS publication SL129, Standard Fertilization Recommendations for Agronomic Crops (https://edis.ifas.ufl. edu/ss163).

Lime, if needed, should be applied three to five months in advance of planting when possible. The recommended nitrogen $(\mathrm{N})$ rate (whole season) depends on plant population and irrigation. UF/IFAS recommendations for nitrogen are based on plant population for grain corn, which is generally lower than for silage corn (20,000 to 30,000 plants per acre for irrigated corn and 10,000 to 15,000 plants per acre for dryland corn). Consider lower and upper range for silage corn plant population between 26,000 and 36,000 for irrigated silage corn, and 15,000 to 23,000 for dryland. For irrigated corn, $\mathrm{N}$ rate ranges from 180 to $240 \mathrm{lb}$ per acre, for low and high population, respectively; while for dryland corn, $\mathrm{N}$ rate ranges from 120 to $180 \mathrm{lb}$ per acre. Phosphorus $\left(\mathrm{P}_{2} \mathrm{O}_{5}\right)$ and potassium $\left(\mathrm{K}_{2} \mathrm{O}\right)$ fertilization should be calculated based on soil levels. Sulfur (S) should be applied at 20-30 lb per acre as sulfate fertilizer (e.g., gypsum, ammonium sulfate, magnesium sulfate, potassium sulfate, potassium magnesium sulfate). Calcium (Ca) and magnesium $(\mathrm{Mg})$ are usually available in adequate amounts when the $\mathrm{pH}$ is corrected to 6.0 or higher. Sandy soils usually require additional boron (B) at $1 \mathrm{lb}$ per acre applied with later applications of $\mathrm{N}$ through the irrigation system. Manure and lagoon effluent typically contain adequate micronutrients in addition to the expected amounts of macronutrients. Note that a potential accumulation of some micronutrients, such as zinc ( $\mathrm{Zn})$, may interfere with other essential nutrients. For example, $\mathrm{Zn}$ may reduce the uptake of $\mathrm{P}$, copper $(\mathrm{Cu})$, and manganese $(\mathrm{Mn})$. Micronutrient analysis can be requested as part of your soil report. Visual evaluations and tissue analysis throughout the season help to diagnose nutrient deficiencies. See Sawyer (2004) for examples of nutrient deficiency.

All of the required $\mathrm{P}_{2} \mathrm{O}_{5}$, a third of the $\mathrm{K}_{2} \mathrm{O}$, and about 30 $\mathrm{lbN}$ per acre as starter fertilizer should be applied at planting as surface dribble [off row, or " $2 \times 2$ " (i.e., two inches to the side and two inches below seeding depth)]. In furrow fertilizeris not recommended because it reduces germination rate. Generally, liquid fertilizer contains N, P, S, and several soluble micronutrients as chelates. They can also be applied as dry fertilizer side dressed, banded, or broadcast. Sidedressing or banding is a preferred form of fertilization for early stages of corn because it increases fertilizer utilization and reduces risk of chemical burn. However, it is sometimes impractical for large acreages. Alternatively, fertilizer can be broadcast.This should be done at early crop growth stages (V2-V4) and applications should occur after the morning dew has dried to avoid plant injury. The remainder of the $\mathrm{N}$ and $\mathrm{K}$ may be applied in split applications but should be completed by six to seven weeks after planting. A good schedule for applying the remaining $\mathrm{N}$ isat $1 / 3$ rate at three, five, and seven weeks after emergence. Supplemental N can be applied overhead through irrigation or as an effluent application later in the season, but no yield improvements are generally observed with $\mathrm{N}$ applications after silk-and-tassel phase. Maturity varies depending on the planted hybrid, but tasseling generally occurs between 55 and 75 days after emergence (Wright et al. 2017). 


\section{Pests and Diseases}

Pest control recommendations change from year to year; consult your local Extension office for the most current recommendations. Planning and preparing are essential for pest and disease management, as is scouting. As mentioned previously, the best defense against many disease problems is genetic resistance through hybrid selection. Proper crop rotation, preparation of the seedbed (through tillage), and nutrition are important cultural aspects of managing pests and diseases. It is important to give the crop the best conditions to survive and produce while reducing or eliminating opportunities for pathogens and weeds to proliferate.

More details regarding pests and diseases can be found in Ask IFAS publication SS-AGR-85, Field Corn Production Guide (https://edis.ifas.ufl.edu/ag202). Ask IFAS publication HS737, Chapter 17: Sweet Corn Production (https:// edis.ifas.ufl.edu/publication/cv135) of the Vegetable

Production Handbook of Florida, brings a comprehensive list of chemicals for sweet corn production. Although many cultural practices differ, information on pest management for sweet corn can be used to reference the choice of product and timing of application in field corn. Information about integrated pest management on corn can be found at https://ipm.ifas.ufl.edu/Agricultural_IPM/Field_Corn. shtml.

\section{WEEDS}

Weed management in corn starts with a clean and prepared seedbed. This is achieved via burndown of winter/spring weeds and a strong pre-emergence herbicide program. There are multiple herbicide options for weed control in corn, and it is essential to use a combination of modes of action to reduce the likelihood of the development of herbicide-resistant weed populations. Select herbicides with residual control, especially for the first phases. Once the corn grows tall enough to shade between the rows, it can outcompete weeds and significantly reduce weed populations. Selective herbicides for later use can have a high cost per acre. Cultivation (mechanical removal) is also an option, but it is generally more expensive and timeconsuming compared to most herbicide applications. Most modern hybrids are also equipped with herbicide resistance packages (e.g., glyphosate, glufosinate), which allow applications of a broad range of products (e.g., Roundup Ready ${ }^{\mathrm{mex}}$, Clearfield $^{\mathrm{rm}}$, LibertyLink ${ }^{\mathrm{Tw}}$ ). Choice of herbicides also depends on the weed spectrum in question, and restrictions applied to corn silage. Always check the label and pay attention to restrictions, withdrawal periods, and residual effects on the subsequent crop being planted. More detailed information and current herbicide recommendations can be found in Ask IFAS publication SS-AGR-02, Weed Management in Corn (http://edis.ifas.ufl.edu/WG007).

\section{NEMATODES}

Nematodes can be a large problem in sandy soils as well as in fields that grow corn continuously, or (because of their large host range) that grow other annual grass crops. If nematodes are expected to be a problem in a particular field, a soil sample should be sent to the Florida Nematode Assay Laboratory (http://entnemdept.ufl.edu/nematologyassay-lab/) to determine the species and populations of plant nematodes in the soil. Sting nematodes (Belonolaimus spp.) are generally the most problematic in sandy soils in Florida, but many others such as needle (Longidorus breviannulatus), stubby-root (Trichodorus spp. and Paratrichodorus spp.), and lance (Hoplolaimus spp.) nematodes can be quite damaging. Depending on population sizes, root-knot nematodes (Meloidogyne spp.) can also be a problem. The most frequent symptoms of nematode damage on corn are patchy, stunted growth despite good fertility practices, root pruning, root bottle brushing, and the formation of root galls.

Management practices for nematodes include crop rotation with non-host crops or fallow, selecting genetic materials tolerant to nematodes, and chemical treatments. Choice of crop rotation depends on the species of nematode that is causing the most damage; frequently, grass crops should be avoided. During fallow periods, weed control is also needed, because nematodes can feed on certain weeds. The use of products like terbufos (Counter ${ }^{\circledR}$ ) and fluopyram (Propulse ${ }^{\circledR}$ ) can be applied in furrow at planting to suppress nematodes. At higher populations, fumigation with chloropicrin $\left(\right.$ Telone $^{\circledR}$ ) might be required but at a very high cost per acre. Seed treated with products like Avicta ${ }^{\circledR}$ or Poncho ${ }^{\circledR} /$ Votivo $^{\circledR}$ is also an alternative control option, but it is not as effective when nematode populations are high. For more information on nematode species, sampling, symptoms, and management, see Ask IFAS publication ENY-001 (https://edis.ifas.ufl.edu/ng014).

\section{INSECTS}

Insects can cause major damage to corn through direct feeding or as disease vectors. Foliage-feeding worms can cause serious damage, especially on late-planted corn. They can reduce growth, limit yield potential, and reduce nutritive value of the plant as well as the quality of silage. A series is available on problematic insects on corn (https:// edis.ifas.ufl.edu/topic_field_corn_pest_insects), and further general recommendations can be found in the Field Corn Production Guide and from your local Extension agent. The 
Georgia Pest Management Handbook for Field Crops offers a section on corn (https://extension.uga.edu/programsservices/integrated-pest-management/publications/handbooks.html\#commercial) that can be used as a reference. However, check the pesticide label before purchasing any product recommended by another state because labels can change regionally.

The first line of defense is choice of hybrid. Most companies offer materials with multiple traits of insect resistance, such as Bt, Cry1 AB, Cry1F, Vip 3A, etc. These acronyms represent the various types of proteins engineered in corn plants that are toxic to insects, but not harmful to other species. Upon consumption, those proteins bind to receptors in the gut and kill the insect. Different insects have different levels of susceptibility to each protein, and some have already developed resistance. Therefore, it is important to find out which species are your primary concern, and choose plant hybrids accordingly. For more information about traits and resistance, check the annually updated Handy Bt Trait Table (https://www.texasinsects.org/bt-corn-trait-table. html). Many companies offer hybrids with "stacked" traits, where multiple genes that express proteins are introduced. Observe the need for planting refuge areas to avoid insect resistance. It is always wise to rotate traits and insecticides if possible.

Most commercially available corn hybrid seeds come pretreated with systemic insecticide such as thiamethoxam (Cruiser ${ }^{\circledR}$ ), or clothianidin (Poncho ${ }^{\circledR}$ or Acceleron ${ }^{\circledR}$ ), which protects the crop in the early phases. In furrow application of insecticides like bifenthrin, terbufos (Counter ${ }^{\circledR}$ ), or tefluthrin at planting can control soil insects such as seed corn maggot, southern corn rootworm, and cutworm. The most worrying foliar insects are corn flea beetles, fall armyworm, corn earworms, and stinkbugs. There are many insecticide options for corn; choice depends on type of pest(s), length of control, cost, and withdrawal period. Always check the label for preharvest intervals. Commonly used insecticides such as $\lambda$-cyhalothrin, chlorantraniliprole (e.g., Besiege ${ }^{\circledR}$ ), bifenthrin (e.g., Brigade ${ }^{\circledR} 2 \mathrm{EC}$, Fanfarem ${ }^{\circledR} 2 \mathrm{EC}$, etc.), chlorpyrifos (e.g., Lornsban ${ }^{\circledR}$ ), zeta-cypermethrin (e.g., Mustang ${ }^{\circledR}$ Maxx), and $\lambda$-cyhalothrin (Warrior ${ }^{\circledR}$ II) have a 21- to 30-day preharvest interval for silage or grazing.

\section{DISEASES}

Similar to insect pests, diseases can take a heavy toll on corn productivity and quality. Diseases cause lesions which damage leaf tissue and reduce photosynthesis. Plants will also increase lignification as a defense response and reduce ear fill capacity. In addition to foliar leaf blights, corn can suffer from root, crown, stalk, and ear rot diseases. The latter is of high importance for silage as it can produce mycotoxins which are detrimental to cattle health or even lethal. Choice of hybrid will have the greatest impact on disease prevention (Figure 2). Disease issues tend to be greater on the second summer crop because of buildup of inoculum and more favorable environmental conditions (humid and hot weather). Like insects, pathogens evolve and adapt to new conditions, genetic pressure, and chemicals. Therefore, it is important to manage diseases carefully, rotate fungicide modes of action, and choose hybrids currently tolerant to the most problematic pathogens. Older materials and practices previously used may not be effective at controlling current pathogens. As a rule of thumb, fungicides should be applied (if needed) around vegetative tassel until reproductive growth stage R1. At this point, 60\% of grain fill will come from the leaves that arise from the ear and up. Field scouting is necessary to gauge whether or not there is $5 \%$ or more of the ear leaf lost to disease lesions. If you have $5 \%$ of the ear leaf covered in lesions at vegetative tassel, a fungicide application will result in yield gain that is equal to or greater than the cost of the application. The most common diseases in Florida affecting silage production are listed in Table 1.

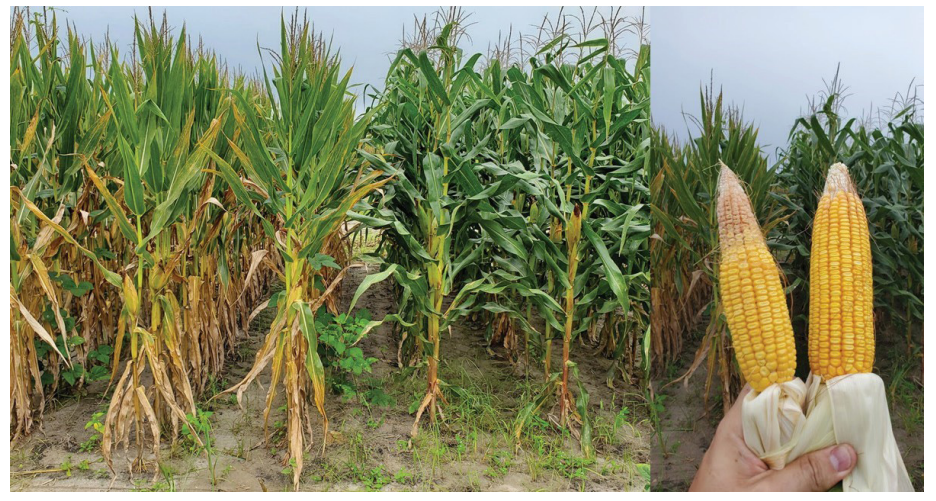

Figure 2. Differences in disease resistance between two corn hybrids (left) and resulting effect on ear fill (right).

Credits: Marcelo Wallau, UF/IFAS

Cultural control methods for corn diseases will vary depending on the target pathogen. Residue-borne pathogens survive in infected plant debris and cannot compete with other soil organisms. If infected plant debris is tilled into the soil, the pathogens will not survive. Soilborne pathogens, however, are capable of surviving in the soil in the presence of other microorganisms. Tillage is not an effective control method for these pathogens and can spread the inoculum. Fungicides are the most used method of control for southern rust (Figure 3C), a very common corn disease in Florida. This particular pathogen does not overwinter in North America and is blown in from South America each year. Early plantings often escape infection 
by southern rust, but late-planted corn is at high risk. Corn ipmPIPE keeps an updated map each year to help track the spread of this disease. This map can be accessed via https:// corn.ipmpipe.org/southerncornrust/.

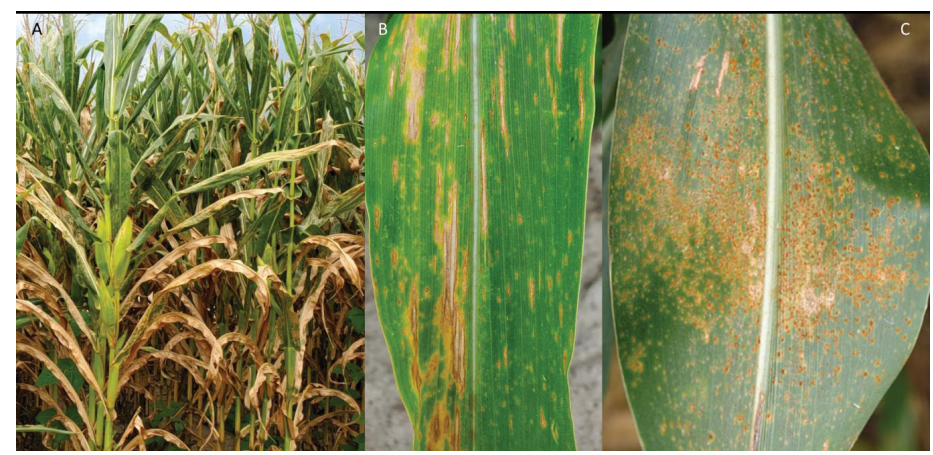

Figure 3. (A-B) Southern corn leaf blight and (C) southern rust on corn. Credits: (A-B) Marcelo Wallau, UF/IFAS; (C) Kevin Korus, UF/IFAS

There are various fungicides that can be used to control or mitigate the effects of fungal diseases in corn. Early fungal diseases, especially soilborne and seedborne ones, can be a threat to seed survival and are controlled by fungicides added as seed treatments. Fungicides such as Captan and fludioxonil (Maxim $\left.{ }^{\circledR}\right)$ are broad-spectrum but not very effective against Pythium, and are generally used along with metalaxyl (e.g., Apron ${ }^{\circledR}$, Allegiance ${ }^{\circledR}$ ). Most seeds are already sold treated, but be aware of the different treatment packages available. Some common fungicide classes used to control corn diseases are the QoI strobilurins, DMI triazoles, and succinate dehydrogenase. The Corn Disease Working Group provides a fungicide efficacy table each year to help growers select a product that works best for them (Wise 2020). Fungicide application timing depends on disease pressure and when symptoms appear during the development of the corn. Data suggests that the best time for application is around vegetative tassel and up to reproductive growth stage 2 or R2. Although these applications may help prevent foliar leaf blights (Figures $3 \mathrm{~A}$ and $3 \mathrm{~B}$ ), they are not effective in reducing corn ear rots (Figure 4) that can lead to mycotoxin development (Anderson et al. 2017).

More information on diseases is available in Ask IFAS publication SS-AGR-85, Field Corn Production Guide (https://edis.ifas.ufl.edu/ag202). An illustrated guide to corn diseases and other issues is available through the University of Georgia Corn Diagnostic Guide (Lee 2012).

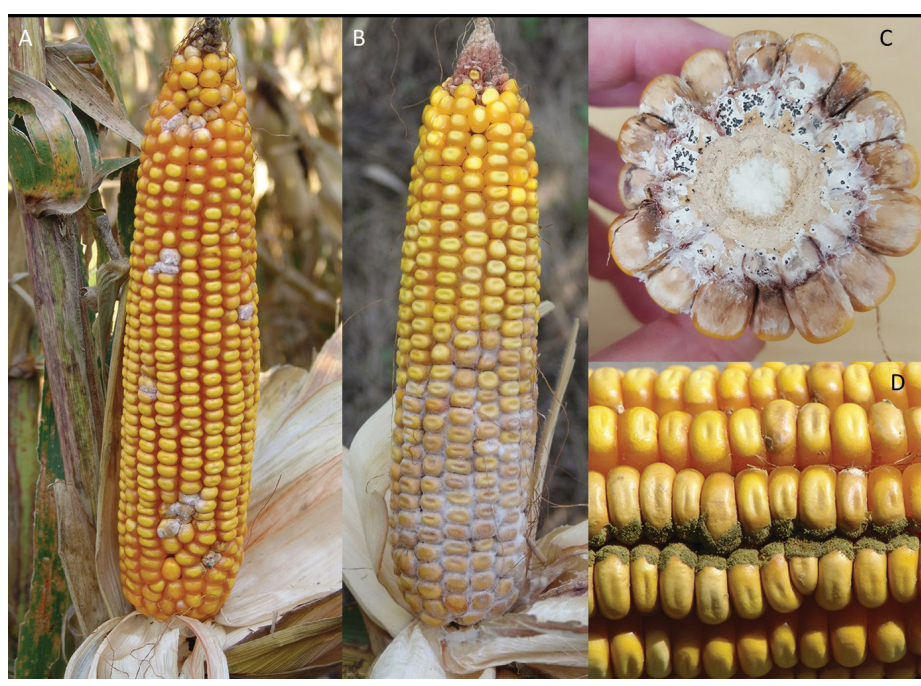

Figure 4. Different ear rots in corn: (A) Fusarium; (B-C) Diplodia; and (D) Aspergillus.

Credits: Tamra Jackson-Ziems, University of Nebraska—Lincoln

\section{When to Harvest}

To optimize yield of dry matter and nutritive value, corn should be harvested for silage when the moisture concentration is approximately $65 \%$ ( $35 \%$ dry matter). Kernel milk line and black layer stages can be used as a reference for approaching harvesting date (Figure 5), but it is important to determine the actual moisture concentration prior to harvesting. Detailed information on methods and calculations for determining moisture on forage crops is available in Ask IFAS publication SS-AGR-178, Methods of Forage Moisture Testing (https://edis.ifas.ufl.edu/ag181). Harvesting when the moisture concentration is more than $70 \%$ (less than $30 \%$ dry matter) can lead to effluent production and low yields, whereas harvesting when moisture concentration is less than $60 \%$ (over $40 \%$ dry matter) can reduce forage nutritive value and compromise packing in bunkers or bags. Corn silage harvested too wet $(<30 \% \mathrm{DM})$ can lead to clostridial fermentation and high butyric acid concentration. If harvested too dry, fermentation is limited and $\mathrm{pH}$ does not drop quickly, resulting in spoilage. For considerable acreage, start harvesting when the forage is at $68-70 \%$ moisture, so that the average DM of all the harvested forage will be about $65 \%$ moisture ( $35 \% \mathrm{DM})$. Harvesting process, inoculation, storage, and feeding are covered in more detail in Ask IFAS publication SS-AGR-177, Silage Harvesting, Storing, and Feeding (https://edis.ifas.ufl.edu/publication/ ag180). 


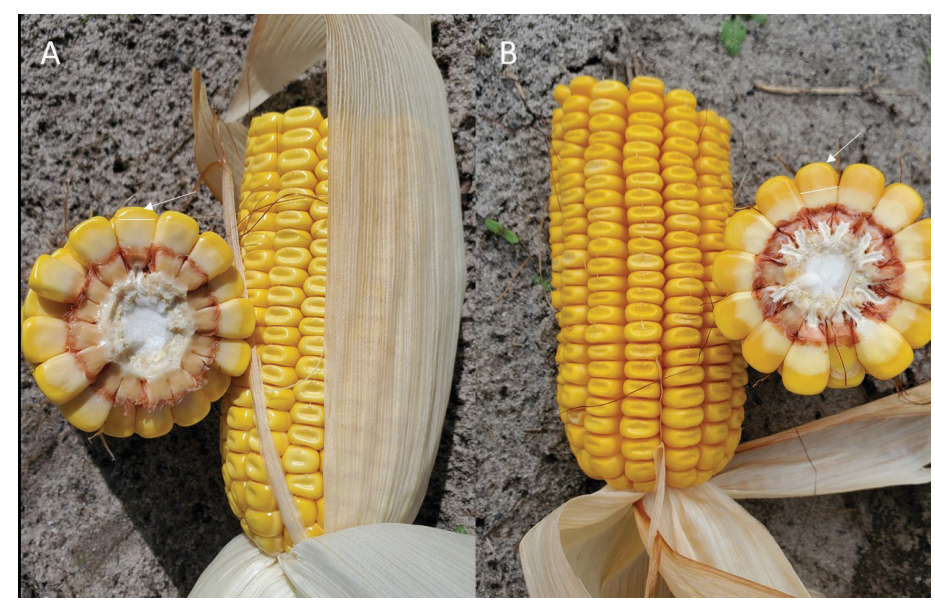

Figure 5. Corn ear at about (A) 3/4 milk line and (B) corn ear at about $1 \frac{1}{2}$ milk line, approaching harvesting time.

Credits: Marcelo Wallau, UF/IFAS

\section{References}

Anderson, N. R., M. P. Romero Luna, J. D. Ravellette, and K. A. Wise. 2017. "Impact of Foliar Fungicides on Gibberella Ear Rot and Deoxynivalenol Levels in Indiana Corn." Plant Health Progress 18:186-191.

Bean, B. W., R. L. Baumhardt, F. T. McCollum, and K. C. McCuistion. 2013. "Comparison of Sorghum Classes for Grain and Forage Yield and Forage Nutritive Value." F. Crop. Res. 142:20-26. doi: 10.1016/j.fcr.2012.11.014.

Lee, D. 2012. "Georgia Corn Diagnostic Guide." University of Georgia Cooperative Extension Bulletin 1221. https://extension.uga.edu/publications/detail. html ? number $=$ B1221\&title $=$ Georgia $\% 20$ Corn $\% 20$ Diagnostic\%20Guide

Oba, M., and M. S. Allen. 1999. "Evaluation of the Importance of the Digestibility of Neutral Detergent Fiber from Forage: Effects on Dry Matter Intake and Milk Yield of Dairy Cows." Journal of Dairy Science 82(3): 589-596. https://doi.org/10.3168/jds.S0022-0302(99)75271-9

Sawyer, J. 2004. "Nutrient Deficiencies and Application Injuries in Field Crops." Iowa State University Extension IMP 42. https://crops.extension.iastate.edu/files/article/ nutrientdeficiency.pdf

Shaver, R. D., J. G. Lauer, J. G. Coors, and P. C. Hoffman. 2006. "Milk2006 Corn Silage: Calculates TDN-1x, NEl-3x, Milk per Ton, and Milk per Acre." Milk 2006corn silagev1. xls. http://www.uwex.edu/ces/dairynutrition/spreadsheets. $\mathrm{cfm}$
Wise, K. 2020. "Fungicide Efficacy for Control of Corn Diseases." Corn Disease Management. CPN-2011-W. https:// crop-protection-network.s3.amazonaws.com/publications/fungicide-efficacy-for-control-of-corn-diseasesfilename-2021-07-14-205804.pdf 
Table 1. Main diseases of corn in Florida.

\begin{tabular}{|c|c|c|}
\hline Disease Type & Disease Name & Pathogen Name \\
\hline \multirow[t]{4}{*}{ Foliar leaf blights } & Southern corn leaf blight ${ }^{R}$ & Bipolaris maydis \\
\hline & Northern corn leaf blight ${ }^{R}$ & Exserohilum turcicum \\
\hline & Common rust ${ }^{R}$ & Puccinia sorghi \\
\hline & Southern rust* & Puccinia polysora \\
\hline \multirow[t]{5}{*}{ Root, crown, and stalk rots } & Pythium root, crown, and stalk rot ${ }^{\varsigma}$ & Pythium spp. \\
\hline & Fusarium root, crown, and stalk $\operatorname{rot}^{\mathrm{s}}$ & Fusarium spp. \\
\hline & Rhizoctonia root rot $^{S}$ & Rhizoctonia spp. \\
\hline & Charcoal $\operatorname{rot}^{\mathrm{S}}$ & Macrophomina phaseolina \\
\hline & Anthracnose stalk rot ${ }^{R}$ & Colletotrichum graminicola \\
\hline \multirow[t]{5}{*}{ Ear rots } & Fusarium ear $\operatorname{rot}^{S}$ & Fusarium spp. \\
\hline & Gibberella ear $\operatorname{rot}^{\mathrm{S}}$ & Gibberella spp. \\
\hline & Diplodia ear $\operatorname{rot}^{R}$ & Diplodia spp. \\
\hline & Aspergillus ear $\operatorname{rot}^{\mathrm{S}}$ & Aspergillus flavus \\
\hline & Penicillium ear $\operatorname{rot}^{R}$ & Penicillium spp. \\
\hline \multicolumn{3}{|l|}{$\begin{array}{l}\text { R Residue-borne. } \\
{ }^{\mathrm{S}} \text { Soilborne. } \\
{ }^{*} \text { Does not over season locally. }\end{array}$} \\
\hline
\end{tabular}

Table 2. Recommended spring planting dates for corn by region in Florida.

\begin{tabular}{|l|l|}
\hline \multicolumn{1}{|c|}{ Region } & \multicolumn{1}{c}{ Dates } \\
\hline South Florida & February 1-March 15 \\
\hline Central Florida & February 1-March 31 \\
\hline Northeastern Florida & February 15-April 15 \\
\hline Northwestern Florida & February 15-April 15 \\
\hline
\end{tabular}

Table 3. Summary of recommendations for corn silage in Florida.

\begin{tabular}{|l|c|l|l|c|}
\hline \multicolumn{1}{|c|}{ Crop } & Planting Dates & \multicolumn{1}{|c|}{ Seeding Rates (lb/A)1 } & \multicolumn{1}{c|}{ When to Harvest } \\
\hline Corn & $\begin{array}{l}\text { South, Feb. 1-Mar. 15 } \\
\text { North, Feb. 15-Apr. 15 }\end{array}$ & $\begin{array}{l}\text { Irrigated: 25,000-35,000 plants/A; } \\
\text { dryland: 15,000-23,000 plants/A }\end{array}$ & $\begin{array}{l}\text { Target harvesting at 65\% moisture. Take } \\
\text { samples to determine moisture content. } \\
\text { Approximately when the kernel milk line is } \\
1 / 2-2 / 3 \text { of the way down the grain. }\end{array}$ & \begin{tabular}{l}
65 \\
\hline
\end{tabular} \\
\hline
\end{tabular}

